\title{
Shale gas development in Canada: What are the potential health effects?
}

\author{
Lalita Bharadwaj PhD, Bernard D. Goldstein MD
}

$\mathrm{U}$ nconventional gas development, including high-volume hydrofracturing (fracking), has enabled a dramatic increase in North American shale gas drilling. In Canada, drilling is taking place in British Columbia and Alberta and is under active consideration in more populated areas of Quebec, New Brunswick and Nova Scotia. Public health and environmental concerns have led to vigorous debate, review by the Chief Medical Officer of Health of New Brunswick and a May 2014 report from the Council of Canadian Academies. ${ }^{1,2}$ In each case, the potential for adverse health effects has been recognized, although there is a paucity of data available to address health concerns. ${ }^{1-4}$

Unconventional gas development involves bending the drilling well shaft laterally within deep underground shale layers and using hydraulically pressurized liquid to fracture the shale, thereby releasing the gas locked within it. The surge in pace, frequency and intensity of shale gas exploration and extraction in the United States has led to public concern and varying responses. Some states have quickly embraced the process; others have imposed a moratorium until the potential health consequences are thoroughly considered.

The potential human health risks associated with fracking fall into two main categories: short-term issues concerning worker and public safety, and long-term health effects resulting from air and water contamination. ${ }^{1,2}$ Some of these risks are common to other energy sources, and proponents of fracking are quick to note the potential health benefits of using natural gas over traditional fuels such as coal.

Public concern often focuses on the chemical and physical agents associated with fracking. The fluid used often contains about $15 \%$ sand, and excessive exposure of workers to silica has been documented. ${ }^{5}$ About $1 \%-2 \%$ of fracking fluid is a mixture of six or more chemicals (Table 1). More than 500 different fracking chemicals are known, some of which are endocrine disrupters. Although methane is relatively nontoxic, it can cause explosions and fires. Shale gas also contains benzene, an agent associated with the development of leukemia. The mixture of agents naturally present underground and brought to the surface dissolved in flowback fluids during and subsequent to well completion contain brine and various amounts of radionuclides, metals and metalloids, such as iron, strontium, barium and arsenic. ${ }^{6}$ In some regions, flowback fluids must be disposed of at the surface, increasing the risk of human exposure. Predicting the toxicity of fracking mixtures is challenging, as is predicting possible chemical reactions that could create additional toxins. ${ }^{6}$

Measurement of air pollutants near drilling sites in Colorado suggested an increase in the risk of noncancer ailments. ${ }^{7}$ An increase in adverse birth outcomes in proximity to drilling sites has also been reported. ${ }^{8}$ Diesel emissions may contribute to the risk of lung cancer and acute respiratory effects such as asthma. The release of hydrocarbons, which varies from site to site, might contribute to ozone health effects in Canada. ${ }^{9}$ Anecdotal reports from residents near shale facilities describe symptoms including headaches, dizziness and nose bleeds. Among the more common self-reported symptoms are fatigue, irritation of the upper respiratory tract, burning eyes and shortness of breath. ${ }^{10,11}$ However, there are no formal epidemiologic studies or health impact assessments that support or refute these observations, or that consider vulnerable populations. ${ }^{1-4}$

Physicians should be aware of the sources of confusion over fracking that have contributed to public distrust and the social amplification of risk. ${ }^{4}$ Seemingly contradictory information about whether fracking is old or new, or has ever

\section{KEY POINTS}

- The human health risks of unconventional gas development are primarily related to worker and public safety issues and to the potential for air and water contamination by hydrofracturing chemicals, shale gas components and naturally occurring agents dissolved underground and returned to the surface as part of the drilling process.

- Competing narratives about health risks have contributed to public uncertainty and to the social amplification of risk.

- Health care workers have a role in insisting on a better understanding of potential health effects of the projected rapid increase in unconventional gas development, particularly in populated areas. 
Table 1: Additives present in hydrofracturing fluids

\begin{tabular}{|lll|}
\hline Type of additive & \multicolumn{1}{c|}{ Example } & \multicolumn{1}{c|}{ Purpose } \\
\hline Acid & Hydrochloric acid & Helps dissolve minerals and start cracks in the rock \\
\hline Antibacterial agent & Glutaraldehyde & Eliminates corrosion-producing bacteria \\
\hline Iron control & Citric acid & Prevents precipitation of metal oxides \\
\hline Breaker & Ammonium persulfate & Allows a delayed break down of the fracturing gel \\
\hline Corrosion inhibitor & N,N-Dimethyl formamide & Prevents corrosion of the pipe \\
\hline Crosslinker & Borates & Maintains fluid viscosity \\
\hline Surfactant & Isopropanol & Increases fluid viscosity \\
\hline Friction reducer & Petroleum distillate & Minimizes friction \\
\hline Gel guar gum & Hydroxyethyl cellulose & Helps suspend sand in water \\
\hline Clay stabilizer & Potassium chloride & Brine carrier fluid \\
\hline pH Adjusting agent & Sodium carbonate & Adjusts and controls $\mathrm{pH}$ of the fluid \\
\hline Scale inhibitor & Ethylene glycol & Reduces scale deposits in pipe \\
\hline
\end{tabular}

caused groundwater contamination, is particularly problematic. Although the fracking process is decades old, the chemicals involved have changed and are now used at much higher volumes and pressures; technical advances allow upwards of 10 wells to be drilled sequentially from the same site, thereby extending industrial activity for many months. The claim that fracking has never contaminated groundwater is true when fracking is defined solely as the successful release of chemicals below groundwater levels. However, contamination has occurred as a result of surface-level incidents, such as the blowout of well casings and leakage from holding ponds. ${ }^{1}$

The biggest short-term risks involve worker and community safety issues, but more needs to be known before health care providers can definitively respond to their patients' and communities' concerns. Local information is important because health effects will vary with geology, geography, demography, population proximity and vulnerability, the development techniques used and the competence and safety culture of the companies and regulatory authorities involved. Physicians may wish to advocate delaying new development activities until the potential health effects are better understood. In those areas committed to unconventional gas development, physicians can advocate for baseline and ongoing exposure and health surveillance to help estimate risk; can help ensure that public health and safety infrastructure is prepared to deal with direct and indirect health issues, including those related to changing workforce demographics; and can insist on effective development-related risk information and vigorous regulatory oversight to lessen health risks.

\section{References}

1. Environmental impacts of shale gas extraction in Canada. Ottawa: The Expert Panel on Harnessing Science and Technology to Understand the Environmental Impacts of Shale Gas Extraction, Council of Canadian Academies; 2014.

2. Chief Medical Officer of Health's recommendations concerning shale gas development in New Brunswick. Fredericton: Office of the Chief Medical Officer of Health (OCMOH) New Brunswick Department of Health; 2012. Available: http://www2.gnb .ca/content/dam/gnb/Departments/h-s/pdf/en/HealthyEnvironments /Recommendations_ShaleGasDevelopment.pdf (accessed 2014 Sept. 22).

3. Korfmacher KS, Jones WA, Malone SL, et al. Public health and high volume hydraulic fracturing. New Solut 2013;23:13-31.

4. Adgate JL, Goldstein BD, McKenzie LM. Potential public health hazards, exposures and health effects from unconventional natural gas development. Environ Sci Technol 2014;48: 8307-20.

5. Esswein EJ, Breitenstein M, Snawder J, et al. Occupational exposures to respirable crystalline silica during hydraulic fracturing. J Occup Environ Hyg 2013;10:347-56.

6. Goldstein BD, Brooks BW, Cohen SD, et al. The role of toxicological science in meeting the challenges and opportunities of hydraulic fracturing. Toxicol Sci 2014;139:271-83.

7. McKenzie LM, Guo R, Witter RZ, et al. Birth outcomes and maternal residential proximity to natural gas development in rural Colorado. Environ Health Perspect 2014;122:412-7.

8. Air health indicators — ozone and fine particulate matter. Ottawa: Environment Canada; 2014. Available: www.ec.gc.ca /indicateurs-indicators/default.asp?lang=en \&n=CB7B92BA-1 (accessed 2014 Apr. 14).

9. McKenzie LM, Witter RZ, Newman LS, et al. Human health risk assessment of air emissions from development of unconventional natural gas resources. Sci Total Environ 2012;424: 79-87.

10. Ferrar KJ, Kriesky J, Christen CL. Assessment and longitudinal analysis of health impacts and stressors perceived to result from unconventional shale gas development in the Marcellus Shale region. Int J Occup Environ Health 2013;19: 104-12.

11. Steinzor N, Subra WA, Sumi L, et al. Investigating links between shale gas development and health impacts through a community survey project in Pennsylvania. New Solut 2013; 23:55-83.

Affiliations: School of Public Health (Bharadwaj), University of Saskatchewan, Saskatoon, Sask.; Graduate School of Public Health (Goldstein), University of Pittsburgh, Pittsburgh, $\mathrm{Pa}$.

Contributors: Lalita Bharadwaj and Bernard Goldstein jointly prepared this submission. 